\title{
Author Correction: A complete domain-to-species taxonomy for Bacteria and Archaea
}

Donovan H. Parks (D), Maria Chuvochina, Pierre-Alain Chaumeil, Christian Rinke (D), Aaron J. Mussig (1) and Philip Hugenholtz (D)

Correction to: Nature Biotechnology https://doi.org/10.1038/s41587-020-0501-8, published online 27 April 2020.

In the version of this article initially published online, the first author of ref. 29 was given as G. M. Barco and the title was given as "A genus definition for Bacteria and Archaea based on genome relatedness and taxonomic affiliation." The correct author is R. A. Barco and the correct title is "A genus definition for Bacteria and Archaea based on a standard genome relatedness index." The error has been corrected in the print, PDF and HTML versions of the article.

Published online: 4 May 2020

https://doi.org/10.1038/s41587-020-0539-7

(c) The Author(s), under exclusive licence to Springer Nature America, Inc. 2020

\section{Publisher Correction: Extending the small-molecule similarity principle to all levels of biology with the Chemical Checker}

Miquel Duran-Frigola (D, Eduardo Pauls, Oriol Guitart-Pla, Martino Bertoni, Víctor Alcalde, David Amat, Teresa Juan-Blanco and Patrick Aloy (1)

Correction to: Nature Biotechnology https://doi.org/10.1038/s41587-020-0502-7, published online 18 May 2020.

In the HTML version of this article initially published online, Patrick Aloy was not listed as a corresponding author.

Published online: 21 May 2020

https://doi.org/10.1038/s41587-020-0564-6

(c) The Author(s), under exclusive licence to Springer Nature America, Inc. 2020

\section{Publisher Correction: Histone-writer cancer drugs enter center stage}

Ken Garber

Correction to: Nature Biotechnology https://doi.org/10.1038/s41587-020-0621-1, published online 5 August 2020.

In the version of this article initially published, a sentence read, "The many non-responders puzzle Roberts, now at St. Jude Children's Research Hospital, because those patients' tumors, too, lack INI1 mutations and have hyperactive EZH2." The patients' tumors lack INI1, not INI1 mutations. The error has been corrected in the PDF and HTML versions of the article.

Published online: 14 August 2020

https://doi.org/10.1038/s41587-020-0672-3

๑ The Author(s), under exclusive licence to Springer Nature America, Inc. 2020 